\title{
PENGARUH PEMBELAJARAN KOOPERATIF JIGSAW DAN MEDIA PEMBELAJARAN TERHADAP PRESTASI BELAJAR PENDIDIKAN AGAMA KRISTEN
}

\author{
Leonardo Talakua \\ leonardotalakua4@gmail.com
}

\begin{abstract}
The purpose of this study was to get empirical data about the effect of cooperative learning jigsaw and the used of media on the Christian Education learning achievement students of SMA Negeri 2 Ambon. The study used quantitative approach with survey design. Population of this researched was all students of SMA Negeri 2 Ambon amount 592 with the sampel was 59 student. Method of data collection used questionnaires and documents, and the questionnaires were tested to 30 student outside the target with validity and reliability test. Hypothesis test used partial test with $t$ test and simultaneous by using SPSS computer program. The result found that there was significant influence between the application of jigsaw learning model to the Christian Education learning achievement of the student of SMA Negeri 2 Ambon. The simple linier line equation formed between the variable of jigsaw learning (X1) with learning media (X2) to the Christian Education learning achievement $(Y)$ was $\breve{Y}=26.219+674(X 1)+112(X 2)$. This finding indicated that there was a positive and significant influenced $74,1 \%$ the application of jigsaw cooperative learning model, together with the student's Christian Education learning achievement of SMA Negeri 2 Ambon in academic year 2017-2018, while the rest equal t0 25,9\% was influenced by other variables which is not examined in this research.
\end{abstract}

Key words: cooperative, jigsaw, media, achievement, Christian

\section{Pengantar}

Pendidikan dimana pun memegang peranan yang penting dan strategis bagi kemajuan dan kesejahteraan suatu bangsa. Ini dikarenakan pendidikan memiliki pengaruh langsung terhadap pengembangan potensi manusia. Untuk meningkatkan kualitas pendidikan di Indonesia telah cukup banyak upaya yang dilakukan, seperti pelatihan dan peningkatan kualifikasi guru, penyempurnaan kurikulum, pengadaan buku dan alat pelajaran, perbaikan sarana dan pra sarana pendidikan lainnya. Walaupun begitu hingga kini mutu pendidikan belum menunjukan peningkatan kearah yang diharapkan sebagaimana mestinya.

Kualitas pendidikan sangat berhubungan dengan sistem pendidikan. Sistem pendidikan dapat dikatakan berkualitas, apabila proses kegiatan belajar mengajar berjalan secara menarik dan menantang, sehingga siswa dapat belajar sebaik mungkin melalui proses belajar yang berkelanjutan. Proses belajar mengajar yang efektif akan mendorong peningkatan mutu pendidikan. Proses tersebut harus disiapkan sebelum ia berproses di kelas. Dalam ranah ini guru memainkan peranan yang strategi, karena guru harus mengorganisasikan materi pelajaran secara maksimal untuk mendapatkan kualitas belajar mengajar yang optimal.
Untuk meningkatkan hasil atau prestasi belajar siswa dalam suatu proses pembelajaran tentu tidaklah mudah seperti yang kita bayangkan. Banyak faktor turut mempengaruhinya. Faktor-faktor itu berupa faktor internal dari diri siswa dan faktor ekternal yang bersumber dari guru dan lingkungan belajar.

Slavin ( 2010 : 4 ) menjelaskan bahwa; Ada banyak alasan yang membuat pembelajaran kooperatif memasuki jalur utama praktik pendidikan. Salah satunya adalah berdasarkan penelitian dasar yang mendukung penggunaan pembelajaran kooperatif untuk meningkatkan pencapaian prestasi para siswa, dan juga akibatakibat positif lainnya yang dapat mengembangkan hubungan antar kelompok, penerimaan terhadap teman sekelas yang lemah dalam bidang akademik. Alasan lain adalah tumbuhnya kesadaran bahwa para siswa perlu belajar untuk berpikir, menyelesaikan masalah, dan mengintegrasikan serta mengaplikasikan kemampuan dan pengetahuan mereka, dan bahwa pembelajaran kooperatif merupakan sarana yang sangat baik untuk mencapai hal-hal semacam itu.

Baugh, menganalisis bahwa terdapat perbedaan yang menonjol antara perolehan hasil belajar melalui indera pandang dan indera dengar. Kurang lebih $90 \%$ hasil belajar seseorang diperoleh melalui 
indera pandang, dan hanya sekitar 5\% diperoleh melalui indera dengar dan 5\% indera lainnya (Arsyad, 2002:8).

Bertolak dari permasalahan dan kajian ilmiah seperti itu maka peneliti ingin untuk memecahkan persoalan prestasi belajar yang dihadapi siswa pada mata pelajaran Pendidikan Agama Kristen di SMA Negeri 2 Ambon. Peneliti ingin melihat apakah dengan menerapkan model pembelajaran kooperatif Jigsaw dan media pembelajaran dalam proses pembelajaran serta secara stimulan berpengaruh secara signifikan bagi peningkatan prestasi belajar siswa SMA Negeri 2 Ambon.

Ada beberapa temuan sebagai permasalahan penelitian yang dianggap sebagai indikator rendahnya prestasi belajar Pendidikan Agama Kristen siswa di SMA Negeri 2 Ambon. Indikator itu antara lain belum ada penelitian yang dilakukan di SMA Negeri 2 Ambon untuk meneliti pengaruh penerapan model pembelajaran kooperatif Jigsaw dan media pembelajaran terhadap prestasi belajar. Melalui hasil observasi dan wawancara dengan beberapa murid ditemukan bahwa prestasi belajar siswa pada mata pelajaran Pendidikan Agama Kristen cenderung rendah dari pelajaran yang lain. Para siswa lebih banyak mendengar guru berceramah dan mencatat materi pelajaran sehingga mengakibatkan kebosanan. Siswa tidak memiliki kesempatan mengeksplor materi pembelajaran.

Dalam observasi juga ditemukan salah satu masalah serius dalam pembelajaran yaitu Attention Deficit Hiperactivity Disorder (ADHD) yaitu, rentan perhatian yang pendek dan mudah teralihkan. Penelitian telah membuktikan bahwa banyak siswa disekolah, dipengaruhi oleh ADHD (Langer, 2008:49)

Melalui hasil observasi dan wawancara dengan guru mata pelajaran sosiologi ditemukan bahwa guru lebih cenderung menerapkan pendekatan ekspositorik; verbalistik dalam pembelajaran. Penerapan pembelajaran konvensional; ceramah dan mencatat mendominasi kegiatan pembelajaran, serta penggunaan media yang terbatas, bahkan mengabaikan media pembelajaran. Guru lebih senang menggunakan model pembeljaran ekspositorik agar mudah dan pengetahuan lebih banyak ditransfer ke otak anak (Solihatin, Raharjo, 2008:2)

Berdasarkan identifikasi masalah di atas, peneliti akan melakukan suatu kajian dengan melakukan perubahan strategi belajar mengajar mata pelajaran Pendidikan Agama Kristen di SMA Negeri 2 Ambon, sehingga dapat diharapkan dengan adanya penggunaan model pembelajaran kooperatif tipe Jigsaw dan penggunaan media pembelajaran, prestasi belajar siswa dapat di tingkatkan.

Penelitian ini bertujuan untuk mengetahui pengaruh pembelajaran kooperatif Jigsaw dan penggunaan media pembelajaran terhadap prestasi belajar Pendidikan Agama Kristen siswa SMA Negeri 2 Ambon.

Penelitian sebelumnya yang berkaitan dengan penelitian ini dilakukan oleh Ardiyanto (2012), terhadap prestasi belajar mata pelajaran akuntansi siswa di SMA Negeri 2 Karanganyar. Berdasarkan hasil penelitian dan analisis data diperoleh harga Me $=85,057$ dan $\mathrm{Mk}=76,800$. Berdasarkan perhitungan yang telah dilakukan dengan t-test diperoleh thitung menunjukkan nilai sebesar 4,715 dan $\mathrm{t}$ menunjukkan nilai 1,998, pada taraf signifikansi $5 \%$ dan $\mathrm{db}=67$. Sehingga dapat disimpulkan bahwa t Hitung > t atau 4,715 > 1,998. Hal tersebut dapat diartikan bahwa nilai rata-rata akhir kelompok eksperimen lebih tinggi daripada nilai rata-rata akhir kelompok kontrol.

Penelitian yang dilakukan Eka Trisianawati, Tomo Djudin dan Rendi Setiawan, menemukan bahwa terdapat peningkatan hasil belajar siswa setelah menggunakan model pembelajaran jigsaw pada materi vector di kelas X SMA Negeri 1 Sanggau Ledo. Rata-rata hasil belajar siswa pada kelas eksperimen sebelum diberikan perlakuan adalah 14,67 meningkat sebesar 70.14 menjadi 84,81 setelah diberikan perlakuan menggunakan model pembelajaran kooperatif jigsaw.

Hasil penelitian lain yang dilakukan oleh Johnson D.W. dan Johnson R, tahun 1989 (Saptono, 2011:82), Slavin (Rusman, 2011:205), Harel, HertzLazarowitz \& Sachar (Sharan, 2014:445) dalam penelitian menemukan guru merasa lebih berhasil ketika mereka menggunakan metode pembelajaran kooperatif karena metode ini memberi mereka caracara yang biasa mereka gunakan unntuk "menarik" 


\section{Leonardo Talakua}

lebih banyak siswa dan melibatkan mereka dalam pembelajaran, tidak seperti bentuk pengajaran tradisional di mana sebagian besar kelas tidak terjangkau oleh proses pembelajaran.

Levie dan Levie (1975) memaparkan hasil-hasil penelitian tentang belajar melalui stimulus gambar (visual) dan stimulus kata (verbal) menyimpulkan bahwa stimulus visual mendorong hasil belajar yang lebih baik untuk tugas-tugas seperti mengingat, mengenali, mengingat kembali dan menghubunghubungkan fakta dan konsep (Arsyad, 2002:9).

bagian ini disajikan latar belakang atau fenomena yang terjadi dan menjadi fokus permasalahan untuk diuraikan secara sistematis, objektif dan kontekstual. Dalam kaitan itu, penulis harus menggunakan hasil-hasil riset berupa jurnal penelitian atau proseding nasional dan internasional yang telah dipublikasi dalam kurun waktu 1-7 tahun terakhir. Ditulis dalam satu paragraf

Sebagai contoh dikemukakan kutipan berikut: Tidak bisa dipungkiri bahwa untuk mewujudkan pendidikan yang bermutu, salah satu instrumen penentunya adalah keberadaan guru yang bermutu juga (Efferi, 2015). Guru sebagai pihak yang terlibat langsung dalam proses pembelajaran di kelas, memiliki peran yang sangat vital dalam meningkatkan kualitas anak didiknya. Keberhasilan proses pendidikan dapat dikatakan sangat tergantung pada peran guru di sekolah (Muhson, 2004). Bahkan, guru merupakan komponen yang paling berpengaruh terhadap terciptanya proses dan hasil pendidikan yang berkualitas (Manik \& Bustomi, 2011).

Selain itu, penulis dapat merujuk pada laporan perkembangan dari lembaga-lembaga resmi terkait misalnya World Bank, UNDP, Unesco, BPS dan atau rujukan lain yang sumber datanya dapat dipertanggungjawabkan. Pada bagian ini, peneliti tidak membangun teori, tetapi menyajikan fakta dan data yang menjadi dasar untuk menetapkan variabel penelitian dan hipotesis yang akan diuji, serta tujuan yang akan dicapai.

\section{Metode}

Penelitian ini bertujuan untuk menguji hipotesis yang telah dikemukakan yakni adanya pengaruh antara variable bebas; pembelajaran kooperatif Jigsaw (X1) dan media pembelajaran (X2) terhadap prestasi belajar (Y) Pendidikan Agama Kristen dan media pembelajaran terhadap prestasi belajar
Pendidikan Agama Kristen pada siswa SMA Negeri 2 Ambon.

Metode yang digunakan dalam penelitian ini adalah metode korelasional kuantitatif, artinya peneliti mencari korelasi yang diartikan sebagai pengaruh antar variable satu atau variable bebas terhadap variable terikat. Dalam menghitungnya digunakan nilai masing-masing variable diolah dengan menggunakan rumus statistik.

Populasi dalam penelitian ini adalah siswa IPS SMA Negeri 2 Ambon. Pengambilan sampel dalam penelitian ini dilakukan dengan teknik propotional random sampling atau sampel proporsi, karena pengambilan sampel, subjek dalam populasi dicampur sehingga setiap subjek dianggap sama untuk memperoleh kesempatan untuk dipilih menjadi sampel. Sedangkan penentuan jumlah sampel diambil dengan menggunakan rumus Slovin. Sampel ditentukan sejumlah $10 \%$ dari populasi atau 592:10 $=59$.

Teknik yang digunakan dalam pengumpulan data adalah metode angket dan dokumentasi. Dalam penelitian ini akan digunakan angket tertutup (angket berstruktur). Sedangkan skala instrumen yang digunakan adalah skala likert. Dalam penelitian ini data yang perlukan dari dokumentasi berupa daftar nilai raport siswa tahun pelajaran 2017-2018, data murid maupun data lain yang dibutuhkan untuk penganalisaan data penelitian. Data penelitian yang dimaksudkan adalah data tentang prestasi belajar (Y).

Cara menentukan valid atau tidaknya instrumen dalam penelitian ini adalah dengan mengkonsultasikan hasil perhitungan korelasi dengan tabel nilai koefisien korelasi pada taraf kesalahan 5\% atau taraf signifikansi 95\% sebesar 0,349 , apabila rhitung > rtabel dengan taraf signifikansi 5\% maka soal dinyatakan valid dan apabila rhitung < rtabel maka soal dinyatakan tidak valid"(Ghozali, 2011:49).

\section{Uji Reliabilitas suatu instrument}

Menurut Ghozali suatu kuesioner dikatakan reliabel atau handal jika jawaban seseorang terhadap pernyataan adalah konsisten atau stabil dari waktu ke waktu. Nunnaly, suatu konstruk atau variabel dikatakan reliabel jika memberikan nilai Cronbach Alpha $>0,60$. Jika nilai Cronbach's Alpha $>0,60$ maka kuesioner yang diuji coba terbukti reliabel.

Uji coba instrument dilaksanakan terhadap 30 siswa dengan menggunakan skala Likert. Jawaban 
setiap item instrumen dengan menggunakan skala Likert mempunyai gradasi/derajat dari sangat positif sampai sangat negatif. Teknik analisa data digunakan teknik regresi untuk mengetahui pengaruh satu variabel terhadap variabel lain (Sugiyono, 2017:189-199)

Analisis data dilakukan melalui beberapa tahap, yaitu: tahap persiapan, uji asumsi klasik, uji normalitas, uji linieritas, uji multikolinieritas. Analisis regresi berganda digunakan untuk mengetahui pengaruh variabel bebas ( $\mathrm{X} 1, \mathrm{X} 2$ ) (penerapan pembelakaran kooperatif Jigsaw dan media pembelajaran) terhadap variabel terikat ( Y ) prestasi belajar. Untuk uji regresi digunakan rumus

$$
\mathrm{Y}=\alpha+\beta 1 \mathrm{X} 1+\beta 2 \mathrm{X} 2
$$

Tahap Uji Hipotesis Penelitian menggunakan Multi Regresi. Pada tahap ini, peneliti menggunakan multi regresi dengan maksud mengetahui pengaruh keseluruhan variabel bebas terhadap variabel terikat. Uji hipotesis dengan mengunakan Uji Parsial (uji T), Uji Simultan (uji T) dan Koefisien Determinasi Simultan (R2)

\section{Hasil}

Pada Deskripsi data penelitian ini disajikan untuk menggambarkan secara utuh kondisi secara kuantitatif responden penelitian. Deskripsi dijabarkan dengan cara menjelaskan hasil analisis tiap variabel penelitian, yakni dua variable bebas; (penerapan model pembelajaran Kooperatif Jigsaw (X1), media pembelajaran (X2), dan variable terikatnya adalah prestasi belajar Pendidikan Agama Kristen (Y).

Pengujian validitas dilakukan dengan perhitungan dengan tehnik korelasi product moment. Hasil uji validasi setiap item pada variable pembelajaran kooperatif jigsaw dan media pembelajaran berjumlah 20 item.

\begin{tabular}{lr}
\multicolumn{2}{c}{ Tabel l. Uji Validitas } \\
\hline \multicolumn{1}{c}{ Variabel } & Corrected Item-Total Correlation \\
\hline Prestasi Belajar Pendidikan & .851 \\
Agama Kristen & \\
Pembelajaran Kooperatif Jigsaw & .916 \\
Media Pembelajaran & .850 \\
\hline
\end{tabular}

Berdasarkan table di atas pada Corrected Item-Total Correlation diketahui bahwa pada masing-masing item pertanyaan mempunyai nilai r hitung 0,916 (X1) dan 0,850 (X2) yang lebih besar dari $r$ table 0,444 dengan nilai signifikasi $p$ $<0,05$, maka dapat disimpulkan bahwa seluruh item pertanyaan pada masing-masing variable, dinyatakan valid.

Teknik analisis data untuk uji normalitas dengan menggunakan P-P Plot dan uji Kolmogorov-Smirnov. Hasil pengujian Kolmogorov-Smirnov ditampilkan sebagai berikut.

Tabel. 2 Ujij Kolmogorov-Smirnov

\begin{tabular}{lr}
\hline & Unstandardized Residual \\
$\mathbb{N}$ & 59 \\
Kolmogorov-Smirnov Z & .914 \\
Asymp. Sig. (2-tailed) & .374 \\
\hline
\end{tabular}

Berdasarkan tabel. 2 diperoleh nilai signifikan dari uji Kolmogorov-Smirnov sebesar 0.374. Karena signifikasi Kolmogorov-Smirnov lebih besar dari alpha $(0,374>0.05)$, maka dapat disimpulkan residual (data) menyebar mengikuti distribusi normal. Sehingga asumsi normalitas terpenuhi.

Hasil analisis regresi linear berganda dengan bantuan SPSS dapat dilihat pada tabel berikut.

\begin{tabular}{|c|c|c|c|c|}
\hline \multirow[t]{2}{*}{ Model } & $\begin{array}{l}\text { Unstandardized } \\
\text { Coefficients }\end{array}$ & & & $\begin{array}{c}\text { Collinearity } \\
\text { Statistics }\end{array}$ \\
\hline & B & $t$ & Sig. & Tolerance VIF \\
\hline 1 (Constant) & 26.219 & 5.898 & .000 & \\
\hline Pembelajaran Kooperatif Jiggaw & 674 & .789 & .000 & 257.894 \\
\hline Media Pembelajaran & 112 & .876 & .385 & 257.894 \\
\hline
\end{tabular}

веraasarkan tapıe 5, така persamaan model regresinya adalah: $\mathrm{Y}=26.219+.674(\mathrm{X} 1)+.112$ (X2). Persamaan model regresi pada table koefisien di atas dapat dijelaskan sebagai berikut:

Hipotesis 1 menyatakan bahwa " Ada pengaruh yang signifikan dari penerapan model pembelajaran kooperatif jigsaw terhadap prestasi belajar Pendidikan Agama Kristen siswa SMA Negeri 2 
Ambon. Dari output diatas dapat diketahui nilai korelasi regresi sederhana maka akan didapat persamaan : $\mathrm{Y}=\mathrm{a}+\mathrm{bx}=26.219+.674 \mathrm{X}$ Diperoleh nilai konstanta sebesar 26.219, artinya jika rasio profitabilitas nilainya 0 , maka audit delay nilainya negative sebesar 26.219. Koefisien regresi variabel Rasio profitabilitas sebesar .674, artinya jika Rasio profitabilitas mengalami kenaikan satu satuan, maka audit deley akan mengalami peningkatan sebesar 674 satuan.

Hasil uji t koefisien Adjusted $R$ Square sebesar .742 sehingga dapat disimpulkan Ho ditolak, hal ini membuktikan penggunaan metode belajar bervariasi mempunyai andil dari adjusted $R$ Square sebesar $74,2 \%$ dari keberhasilan dalam proses belajar yang ditandai dengan nilai prestasi dari siswa tersebut dengan sig sebesar 0,000 .

Tabel4. Cjit (Besarnaya Pengarulh XIdan Xi Terhadap Y)

\begin{tabular}{|c|c|c|c|}
\hline Nodole & R RSploxe & Adjosted RSpquare & Duxidin-Nataron \\
\hline XI & $\begin{array}{ll}8664 & .746\end{array}$ & .742 & \\
\hline X2 & .774 & 593 & \\
\hline
\end{tabular}

\section{Uji Hipotesis 2}

Dari hipotesis 2 dinyatakan bahwa "Ada pengaruh yang signifikan dari media pembelajaran terhadap prestasi belajar Pendidikan Agama Kristen siswa SMA Negeri 2 Ambon. Dari output di atas (tabel.3 dapat diketahui nilai korelasi regresi sederhana maka akan didapat persamaan : $\mathrm{Y}=\mathrm{a}+\mathrm{bX}=$ $26.219+.112$ X. Diperoleh nilai konstanta sebesar 26.219 artinya jika rasio profitabilitas nilainya 0 , maka audit delay nilainya negative sebesar 26.219. Koefisien regresi variabel Rasio profitabilitas sebesar .112 artinya jika Rasio profitabilitas mengalami kenaikan satu satuan, maka audit deley akan mengalami peningkatan sebesar .112 satuan.

Dari hasil uji t pengaruh variabel $\mathrm{X} 2$ terhadap $\mathrm{Y}$ (tabel 4), koefisien Adjusted R Square sebesar .593 sehingga dapat disimpulkan Ho ditolak, hal ini membuktikan media pembelajaran mempunyai andil dari Adjusted $R$ Square sebesar 59,3 \% dari keberhasilan dalam proses belajar yang ditandai dengan nilai prestasi dari siswa tersebut dengan sig sebesar 0,00, pada hasil uji parsial.

\section{Uji Hipotesis 3}

Hipotesis 3 penelitian ini menyatakan bahwa " Ada pengaruh yang signifikan antara penerapan model pembelajaran kooperatif jigsaw dan media pembelajaran secara bersama-sama terhadap prestasi belajar Pendidikan Agama Kristen siswa SMA Negeri 2 Ambon. Dari output diatas dapat diketahui nilai analisis regresi linier berganda maka di dapat persamaan : $\mathrm{Y}=\mathrm{a}+\mathrm{b}_{1} \mathrm{X}_{1}+\mathrm{b}_{2} \mathrm{X}_{2}, \mathrm{Y}=26.219+$ $.674 \mathrm{X}_{1}+.112 \mathrm{X}_{2}$.

Analisis determinasi simultan digunakan untuk mengetahui prosentase sumbangan pengaruh variabel independen secara bersama- sama terhadap variabel dependen. Hasil analisis determenasi dapat dilihat pada output Model summary dari hasil analisis regresi linier berganda di bawah ini.

\section{Tabel 5 . Hasil Koetisien Determimasi Simultan}

\begin{tabular}{|c|c|c|c|c|}
\hline Model & $R$ & RSguare & Adjusted R Suare & Durbin-Watson \\
\hline 1 & 866 & .749 & .741 & 1.987 \\
\hline
\end{tabular}

Menurut Santoso (2001) bahwa untuk regresi dengan lebih dari dua variabel bebas digunakan Adjusted $R^{2}$ sebagai koefisien determinan. Adjusted $R$ Square adalah nilai $R$ Square yang telah disesuaikan. Berdasarkan output diperoleh angka Adjusted R square sebesar .741.

\section{Pembahasan}

Hasil penelitian ini menunjukkan bahwa terdapat pengaruh positif dan signifikan penggunaan model pembelajaran Kooperatif Jigsaw terhadap prestasi belajar mata pelajaran Pendidikan Agama Kristen SMA Negeri 2 Ambon. Hal ini ditunjukkan dengan signifikansi koefisien $F_{\text {hitung }}$ sebesar 12.941 $>$ dari $\mathrm{F}$ table 2,002 pada taraf signifikasi sebesar 0,00 . Persamaan garis linier sederhana yang terbentuk antara variabel penerapan model pembelajaran kooperatif Jigsaw $\left(\mathrm{X}_{1}\right)$ dengan $\mathrm{Y}$ adalah $\breve{\mathrm{Y}}=26.219+.742 \mathrm{X}$. Hasil statistic tersebut menunjukkan bahwa penerapan model pembelajaran kooperatif jigsaw dapat memberikan kontribusi yang signifikan terhadap prestasi belajar Pendidikan Agama Kristen dengan sumbangan sebesar 74,2 \%. Artinya makin baik penerapan model pembelajaran kooperatif Jigsaw, maka akan semakin meningkat pula prestasi yang diraih oleh siswa. 
Terdapat pengaruh yang signifikan media pembelajaran terhadap prestasi belajar Pendidikan Agama Kristen siswa SMA Negeri 2 Ambon. Hal ini ditunjukkan dengan sigfinikansi koefisien $F_{\text {hitung }}$ sebesar $9.238>$ dari $F_{\text {table }} 2,002$ pada taraf signifikasi sebesar 0,00. Persamaan garis linier sederhana yang terbentuk antara variable media pembelajaran $\left(\mathrm{X}_{2}\right)$ dengan prestasi belajar Pendidikan Agama Kristen (Y) pada siswa SMA Negeri 2 Ambon adalah $\breve{\mathrm{y}}=26.219+593$. Hasil statistic tersebut menunjukkan bahwa media pembelajaran dapat memberikan kontribusi yang signifikan terhadap prestasi dengan sumbangan 59,3 $\%$. Artinya makin meningkat penerapan media pembelajaran, maka akan semakin meningkat pula prestasi yang diraih oleh siswa tersebut.

Terdapat pengaruh yang signifikan antara penerapan model pembelajaran kooperatif jigsaw dan media pembelajaran terhadap prestasi belajar Pendidikan Agama Kristen siswa SMA Negeri 2 Ambon. Dari hasil perhitungan SPSS Versi 18 menunjukkan bahwa prestasi belajar Pendidikan Agama Kristen siswa SMA Negeri 2 Ambon, dapat dipengaruhi oleh penerapan model pembelajaran kooperatif jigsaw dan media pembelajaran, hal ini dapat dinyatakan dengan hasil signifikansi $F_{\text {hitung }} 83.770>$ $F_{\text {tabel }}$ 4.01pada uji simultan. Persamaan regresi ditunjukkan oleh persamaan $\breve{\mathrm{Y}}=26.219+.674 \mathrm{X}_{1}$ $+.112 \mathrm{X}_{2}$.

Temuan tersebut menunjukkan bahwa terdapat pengaruh positif dan signifikan sebesar $74,1 \%$ penerapan model pembelajaran kooperatif Jigsaw dan media pembelajaran, secara bersama- sama terhadap prestasi belajar Pendidikan Agama Kristen siswa SMA Negeri 2 Ambon. Hasil penelitian ini menemukan bukti bahwa penerapan model pembelajaran kooperatif jigsaw dan media pembelajaran berpengaruh secara bersama terhadap prestasi belajar. Sangat singifikan untuk diterapkan dalam proses belajar.

\section{Simpulan}

Ada pengaruh yang signifikan penggunaan pembelajaran kooperatif jigsaw terhadap prestasi belajar Pendidikan Agama Kristen siswa SMA Negeri 2 Ambon. Hal ini dibuktikan dengan nilai untuk variable pembelajaran kooperatif jigsaw (X1) pada kolom Sig. adalah 0.000 kurang dari alpha 0.05 dan nilai thitung lebih besar dibandingkan dengan ttabel pada taraf signifikan 5\% yaitu $12.941>2.002$. Hasil statistic juga menunjukan bahwa penggunaan pembelajaran kooperatif jigsaw dapat memberi kontribusi atau pengaruh yang signifikan terhadap prestasi belajar Pendidikan Agama Kristen dengan hitung sumbangan sebesar $74.2 \%$. Artinya semakin baik penggunaan pembelajaran kooperatif jigsaw, maka akan semakin meningkat pula prestasi yang diraih siswa.

Ada pengaruh yang signifikan media pembelajaran terhadap prestasi belajar Pendidikan Agama Kristen siswa SMA Negeri 2 Ambon. Hal ini dibuktikan dengan nilai untuk variable media pembelajaran (X2) pada kolom Sig. adalah 0.000 kurang dari alpha 0.05 dan nilai thitung lebih besar dibandingkan dengan ttabel pada taraf signifikan 5\% yaitu $9.238>2.002$. Hasil statistic juga menunjukan bahwa media pembelajaran dapat memberi kontribusi atau pengaruh yang signifikan terhadap prestasi belajar Pendidikan Agama Kristen dengan hitung sumbangan sebesar $59.3 \%$. Artinya semakin baik penggunaan media pembelajaran, maka akan semakin meningkat pula prestasi yang diraih siswa.

Ada pengaruh yang signifikan penggunaan pembelajaran kooperatif jigsaw dan media pembelajaran secara simultan terhadap prestasi belajar Pendidikan Agama Kristen siswa SMA Negeri 2 Ambon. Hal ini dibuktikan dengan nilai Fhitung lebih besar dibandingkan dengan Ftabel pada taraf signifikasi 5\% yaitu $83.770>4.01$. Persamaan garis linier yang terbentuk antara variable pembelajaran kooperatif jigsaw (X1) dan media pembelajarani $\left(\mathrm{X}_{2}\right)$ dengan prestasi belajar Pendidikan Agama Kristen (Y) adalah Y $=26.219+$ $.674(\mathrm{x} 1)+.112(\mathrm{x} 2)$ bernilai positif. Begitu pula dengan hasil koefisien determinasi simultan $\left(R^{2}\right)$. Temuan tersebut menunjukkan bahwa terdapat pengaruh positif dan signifikan sebesar $74,1 \%$ pembelajaran kooperatif jigsaw dan media pembelajaran, secara bersama- sama terhadap prestasi belajar Pendidikan Agama Kristen siswa SMA Negeri 2 Ambon. Sedangkan sisanya sebesar $25,9 \%$ dipengaruhi oleh variabel lain yang tidak diteliti dalam penelitian ini. 


\section{Saran Dan Rekomendasi}

Dari hasil penelitian ini, penulis melihat bahwa seorang guru hendaknya mampu memahami dan mampu menggunakan berbagai macam-macam merode dalam mengajar sehingga peserta didik bisa termotivasi untuk mengikuti pelajaran. Salah satu yang bisa digunakan oleh seorang guru adalah pembelajaran kooperatif jigsaw.

\section{Ucapan Terima Kasih}

Pada kesempatan ini, terimakasih saya ucapkan kepada redaktur yang telah memberikan masukan yang berharga sehingga tulisan ini dapat disajikan di jurnal Institutio. Terimakasih juga saya ucapkan kepada seluruh dewan redaksi jurnal Institutio yang sudah memberikan ruang diskusi. Semoga bantuan dan dukungannya mendapatkan balasan yang sebanyak-banyaknya dari Tuhan kita Yesus Kristus, Amin. .

\section{Pustaka Acuan}

Aqib, Zainal. 2013. Model-Model, Media dan Stategi Pembelajaran Kontekstual (Inovatif). Bandung: Yrama Widya.

Andari Mia (2006) tentang "Pengaruh Penerapan Cooperative Learning Tipe Jigsaw Terhadap Pemahaman Siswa pada pokok bahasan larutan Elektronik".

Ardiyanto, Agus judul tesis "Efektivitas penerapan model kooperatif tipe jigsaw terhadap prestasi belajar mata pelajaran akuntansi siswa di SMA Negeri 2 karanganyar tahun pelajaran 2011/2012"

Arikunto, S. 1997. Prosedur Penelitian suatu Pendekatan Praktek, Jakarta: Reneka cipta

1997. Dasar-Dasar Evaluasi
Pendidikan, Jakarta: PT. Bumi Akasara.

Arsyad, Azhar. 2002. Media Pembelajaran, Jakarta : PT Raja Grafindo Persada.

Ghozali, Imam. 2011. Aplikasi Analisis Multivariate dengan Program SPSS. Semarang: Badan Penerbit Universitas Diponegoro.
Kurniawan Robert \& Yuniarto Budi. 2016. Analisis Regresi Dasar dan Penerapannya dengan $R$. Jakarta: PT. Karisma Putra Utama.

Langer, Ellen J. 2008. Mindful Learning, membongkar 7 mitos pembelajaran yang menyesatkan. Jakarta: Penerbit Erlangga.

Rusman, 2011. Model-Model Pembelajaran Mengembangkan Profesionalisme Guru. Jakarta : Rajawali Pers

Saptono. 2011. Dimensi-Dimensi Pendidikan Karakter, Wawasan, Strategi Dan Langkah Praktis. Salatiga: Penerbit Erlangga

Slavin, R.E. 2010. Cooperative Learning Teori, Riset dan Praktik, Bandung; Nusa Media.

Sharan, Shlomo. 2014. The Handbook Of Cooperative Learning, inovasi Pengajaran dan Pembelajaran Untuk memacu Keberhasilan siswa di kelas. Yogyakarta: Istana Media.

Solihatin, E \& Raharjo. 2008. Cooperative Learning Analisis Model Pembelajaran IPS, Jakarta: Bumi Aksara

Sugiyono. 2017. Statistika Untuk Penelitian. Bandung: Alfabeta.

2017, Metode Penelitian Pendidikan, Pendekatan kuantitatif, kualitatif, dan $R \& D$. Bandung: Alfabeta.

Artikel Jurnal

Eka Trisianawati, Tomo Djudin, \& Rendi Setiawan (2016). Pengaruh Model Pembelajaran Kooperatif Tipe Jigsaw Terhadap hasil Belajar Siswa Pada Materi Vektor Di Kelas X SMA Negeri 1 Sanggau Ledo. JurnPada Materi Vektor Di Kelas X SMA Negeri 1 Sanggau Ledo. Jurnal Fisika dan Aplikasinya. Vol 06, No 02 Desember 2016 